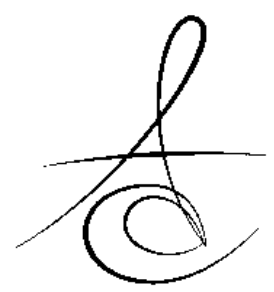

\title{
TRABZON İLINNDE, 3-6 YAŞ GRUBU ÇOCUKLARDA ERKEN ÇOCUKLUK ÇAĞI ÇÜRÜĞÜ PREVALANSI VE İLİŞKİLI RİSK FAKTÖRLERİNİN DEĞERLENDİRİLMESİ
}

\author{
PREVALENCE OF EARLY CHILDHOOD CARIES AND ASSOCIATED RISK \\ FACTORS AMONG 3-6-YEAR-OLD CHILDREN IN TRABZON
}

\author{
Dr. Öğr. Üyesi Sema AYDINOĞLU*
}

Doç. Dr. Adem KUŞGÖZ**

Makale Kodu/Article code: 3964

Makale Gönderilme tarihi: 28.01 .2019

Kabul Tarihi: 16.04 .2019

\section{ABSTRACT}

Aim: The aim of this survey is to evaluate the relationship between dmf-t index and various risk factors such as age, gender, socioeconomic status, nutrition and oral health habits of 1083 preschool children who have been attending the preschools in Trabzon.

Material and Methods: Children, ages between 3 and 6 years old from 7 state schools and 1 private school, have been included for this research. Questionnaires were used to collect the necessary data. Children were examined using an intraoral mirror and a probe in a day light. The chi-square test was used to analyze data. In addition, multivariable logistic regression analysis was performed to evaluate the magnitude of the relationship between dental caries and its associated risk factors.

Results: The results revealed that the prevalence of ECC in preschool children was $63.1 \%$ and that of SECC was $20.4 \%$. The mean dmf-t score was found to be $2.95 \pm 3.60$. It was shown that ECC prevalence and mean dmf-t increased significantly with age. The prevalence of ECC was significantly higher in children who were breastfed for longer than six months, those who had never brushed their teeth and those who had a previous dental visit. However, yogurt and cheese consumption was statistically significant in preventing ECC and affecting the severity of dental caries.

Conclusion: The most important data which is necessary to determine the dental treatment requirements of communities is obtained from the dmft indicies, oral health habits, nutrition and socioeconomic status. Studies in this direction make contribution to raise oral health knowledge level and consciousness of parents.

Key Words: Early childhood caries, Preschool children, Caries prevalence, ECC

\section{öz}

Amaç: $\mathrm{Bu}$ çalışmanın amacı, Trabzon ilindeki anaokullarında öğrenimine devam etmekte olan 1083 okul öncesi çocuğun çürük (decayed) kayıp (missing) dolgulu (filled) diş (teeth) (dmf-t) indeks değerlerinin yaş, cinsiyet, sosyoekonomik durum, ağız sağlığı alışkanlıkları ve beslenme gibi çeşitli risk faktörleri ile olan ilişkisini değerlendirmektir.

Gereç ve Yöntem: Biri özel olmak üzere sekiz anaokulunda öğrenimine devam etmekte olan 3-6 yaş arası çocuklar bu araştırmaya dahil edildi. Gerekli verilerin elde edilebilmesi için çocukların beslenme ve ağız sağlığı alışkanlıkları ile ilişkili soruları içeren anket formları velilere gönderildi. Çocukların ağız içi muayeneleri Dünya Sağlık Örgütü (WHO) kriterlerine göre, gün ışığında ayna ve sond yardımıyla yapılarak dmf-t indeksleri kayıt altına alındı. Araştırmada elde edilen tüm veriler ki-kare testi uygulanarak hesaplandı. Akabinde istatistiksel olarak anlamlı bulunan verilere lojistik regresyon analizi yapıldı.

Bulgular: Yapılan değerlendirmeler sonucunda, erken çocukluk çağı çürüğü (EÇÇ) ve şiddetli erken çocukluk çağı çürüğü (Ş-EÇÇ) prevalansları sırasıyla; \%63.1 ve 20.4 olarak tespit edildi. Ortalama dmf-t değeri $2.95 \pm$ 3.60 olarak bulundu. EÇÇ prevalansının ve ortalama dmf-t skorunun yaşla beraber anlamlı şekilde arttığı görüldü. EÇÇ sıklığının altı aydan fazla anne sütü alanlarda, dişlerini hiç fırçalamayanlarda ve daha önce hiç diş hekimine gitmeyen çocuklarda daha yüksek olduğu belirlendi. Yoğurt ve peynir tüketiminin ise; çocuklarda diş çürüğünü önlemede ve çürüğün şiddetini azaltmada istatistiksel olarak önemli olduğu saptandı.

Sonuç: Trabzon İlindeki okul öncesi çocuklardaki çürük prevalansının çok yüksek olduğu görüldü. Bir topluluğun dental tedavi ihtiyacının tespitinde gerekli olan en önemli bilgiler dmf-t indeksleri, ağız sağlığı alışkanlıkları, beslenme ve sosyodemografik unsurlardan elde edilmektedir. Bu yönde yapılan araştırmalar ile ağız sağlığı konusunda bilgi düzeyinin artmasına ve ebeveynlerin bilinçlendirilmesine katkıda bulunulabilir.

Anahtar kelimeler: Erken çocukluk çağı çürüğü, Okul öncesi çocuklar, Çürük sıklığı, EÇÇ

\footnotetext{
*Recep Tayyip Erdoğan Üniversitesi Diş Hekimliği Fakültesi Pedodonti A D, Rize.
}

**özel Diş Hekimi 


\section{INTRODUCTION}

Early childhood (3-5 years old) is an important period in terms of physical, mental and psychological development. In this period, one of the most common seen diseases is early childhood caries (ECC), which is chronic, irreversible, multifactorial and infectious. ${ }^{1}$ ECC is defined as the presence of one or more decayed (with or without cavitation), missing (due to caries), or filled primary teeth by the age of 71 months or younger. ${ }^{2}$ From ages 3 to 5 , a decayed, missing (due to caries) or filled score of $\geq 4$ (age 3 ), $\geq 5$ (age 4), or $\geq 6$ (age 5 ) represents severe early childhood caries (S-ECC). ${ }^{3}$

Despite protective applications to prevent dental caries, ECC is still an important health problem worldwide. ${ }^{4}$ ECC is often especially encountered in developing countries and low socioeconomic regions of some developed countries. ${ }^{5}$ The National Health and Nutrition Examination Survey (NHANES) reported a decrease in the prevalence of ECC in 3-5-year-old children from $33.3 \%$ in the years spanning 1999 to 2004 to $27.9 \%$ in the years spanning 2011 to 2012 . It is estimated that the prevalence will be $30 \%$ in the 2020 s in this young age group. ${ }^{6}$

The prevalence of ECC changes depending on the cultural habits related to babies' nutrition. $^{7}$ According to the review of the actual literature, in the less developed countries the prevalence rate of ECC is aproximately $70 \%$ whereas in the most developed countries ECC prevalence has been found between 1 and $12 \% .^{8}$ Another study was conducted in three different city centres of Turkey and showed that ECC is still an important health issue. According to the results of a previous study, the caries prevalence of preschool children in Mardin, Karaman and Kütahya was $18.1 \%, 33.0 \%$ and $78.4 \%$, respectively. ${ }^{9}$

The aetiology of ECC is well understood and multifactorial in nature. The main step in the occurrence of ECC in young children is the accumulation of cariogenic microorganisms, especially mutans streptococci. ECC is frequently related to the consumption of cariogenic foods and insufficient oral health habits. A window of infectivity was determined as a period from 19 to 31 months of age when microorganisms are transported easily from the caregiver, especially mother to child. ${ }^{10}$ Additionally, it is believed that socioeconomic status, education level of parents, oral hygiene practices, fluoride application and genetic factors are associated with early childhood caries. ${ }^{11,12}$

This study sought to evaluate the prevalence of ECC, dmf-t index and its associated dietary factors in 3-6-year-old children in Trabzon. In addition, it aimed to instruct and create awareness among preschool teachers and parents about early childhood caries and to emphasize the significance of preventive dentistry.

\section{MATERIAL and METHODS}

\section{Institutional ethical committee}

This study was approved by the ethical committee of Medical Faculty of Karadeniz Technical University. An informed consent form was obtained from each parent who answered a questionnaire form before the dental examination.

\section{Sampling and sample size}

Before the beginning of the study, the total number of students $(n=10.894)$ going to preschools that are directly dependent on the Trabzon Provincial Directorate of National Education was calculated.

Power analysis was conducted to determine sample size for this study. The minimum sample size $(n=664)$ was calculated before study initiation based on an ECC prevalence of $50 \%$ (estimated ECC prevalence in this population), with a margin of error of $5 \%$ and a $95 \%$ confidence level. ${ }^{13}$ Considering exclusion factors (unwilling to complete the survey, answering questions improperly or non-response bias), 1077 children were included in this research.

Eight private and state preschools with different socioeconomic statuses (low-medium-high) were selected.

\section{Study design}

This report presents a community-based crosssectional study.

\section{Inclusion criteria}

Children aged from 36 to 71 months who currently attended one of the state or private preschools mentioned above, presented to school on the day of the examination, and whose parents signed a consent form before the study and permitted a dental examination were included this study. 


\section{Data collection}

\section{Intraoral examination}

Intraoral examination of the children was performed according to the World Health Organization (WHO) criteria. ${ }^{14}$ Each child was examined in the school under a visible light using a probe and mouth mirror. Before dental examination, children did not brush their teeth, and no professional tooth cleaning procedures were performed. A primary tooth was recorded decayed (d) if there was a cavitated or noncavitated carious lesion, filled ( $f$ ) if there was a restoration on the tooth and missed $(\mathrm{m})$ if the tooth was extracted due to caries. Radiography was not used in this study.

\section{Oral health questionnaire}

For each child who participated in the survey, a questionnaire, which consisted of sociodemographic data, oral hygiene practices and dietary habits, was delivered to the parents.

\section{Statistical analysis}

Statistical analyses were performed utilizing the Statistical Package for Social Sciences (SPSS version 22, Chicago, IL, USA). The relationship between ECC and possible risk factors was compared using the Chisquare test. Multiple logistic regression analysis was performed on the data that was statistically significant. A significance level of $5 \%(P<.05)$ was adopted for all statistical tests.

\section{RESULTS}

This study was carried out to evaluate the prevalence of ECC in Trabzon and to examine its possible risk factors.

\section{Socio-demographic profile}

The prevalence of ECC and S-ECC and their relationship with sociodemographic variables are shown in Table 1. Of the 1077 children studied, 397 (36.9\%) were non-carious and $680(63.1 \%)$ had ECC. Additionally, $20.4 \%$ of the children that was examined had severe ECC. In the gender-wise distribution of ECC, $335(66.7 \%)$ of the children who had nursing caries were girls, and $208(38.9 \%)$ of the children who had no caries were boys. However, there was no significant difference associated with presence of ECC between girls and boys in this study $(P>.05)$.

There were 48 three-year-old children with ECC (47.1\%), 199 four-year-old children (54.8\%), and 363 five-year-old children (71.7\%). As shown in Table 2, the mean dmf-t score was $2.95 \pm 3.60$. According to the ages of children examined in the study, ECC prevalence and mean dmf-t increased significantly with age $(P<.001): 2.01 \pm 3.44$ at 3 years of age, $2.40 \pm 3.42$ at 4 years of age and $3.51 \pm 3.70$ at 5 years of age.

Table 1. Prevalence and univariate variable analysis of sociodemographic attributes associated with ECC and S-ECC $(n=1077)$

\begin{tabular}{|c|c|c|c|c|c|c|c|}
\hline Variable & $\begin{array}{c}\text { All children } \\
(\mathrm{n}=1077) \\
\%(\mathrm{n})\end{array}$ & $\begin{array}{c}\text { ECC } \\
(n=680) \\
\%(n)\end{array}$ & $\begin{array}{c}\text { Non-ECC } \\
(\mathrm{n}=397) \\
\%(\mathrm{n})\end{array}$ & P-value & \begin{tabular}{|c|} 
S-ECC \\
$(n=220)$ \\
$\%(n)$
\end{tabular} & \begin{tabular}{|c|} 
Non-ECC \\
$(\mathrm{n}=397)$ \\
$\%(\mathrm{n})$
\end{tabular} & P-value \\
\hline \multicolumn{8}{|c|}{ SEX $^{A}$} \\
\hline Male & $49.9(535)$ & $61.1(327)$ & 38.9 (208) & 0.060 & $34.8(111)$ & $65.2(208)$ & 0.237 \\
\hline Female & $46.8(502)$ & $66.7(335)$ & $33.3(167)$ & & $39.5(109)$ & $60.5(167)$ & \\
\hline \multicolumn{8}{|c|}{ AGE (YEARS) ${ }^{A}$} \\
\hline 3 & $9.5(102)$ & $47.1(48)$ & $52.9(54)$ & $<0.001$ & $26.0(19)$ & $74.0(54)$ & $<0.001$ \\
\hline 4 & $33.8(363)$ & $54.8(199)$ & $45.2(164)$ & & $29.6(69)$ & $70.4(164)$ & \\
\hline 5 & $47.2(506)$ & $71.7(363)$ & $28.3(143)$ & & $48.0(132)$ & $52.0(143)$ & \\
\hline \multicolumn{8}{|c|}{ MOTHER'S EDUCATION LEVEL ${ }^{A}$} \\
\hline $\begin{array}{l}\text { Primary } \\
\text { school }\end{array}$ & $9.4(101)$ & $63.4(64)$ & $36.6(37)$ & 0.859 & $36.2(21)$ & $63.8(37)$ & 0.938 \\
\hline Middle school & $33.6(360)$ & $63.3(228)$ & $36.7(132)$ & & $34.7(70)$ & $65.3(132)$ & \\
\hline $\begin{array}{l}\text { High school } \\
\text { /University }\end{array}$ & $36.1(387)$ & $61.5(238)$ & 38.5 (149) & & $33.8(76)$ & $66.2(149)$ & \\
\hline \multicolumn{8}{|c|}{ FATHER'S EDUCATION LEVEL ${ }^{A}$} \\
\hline $\begin{array}{l}\text { Primary } \\
\text { school }\end{array}$ & $7.5(81)$ & $64.2(52)$ & $35.8(29)$ & 0.956 & $38.3(18)$ & $61.7(29)$ & 0.518 \\
\hline Middle school & $35.3(379)$ & $62.5(237)$ & $37.5(142)$ & & $31.7(66)$ & $68.3(142)$ & \\
\hline $\begin{array}{l}\text { High school } \\
\text { /University }\end{array}$ & $36.3(389)$ & $62.5(243)$ & 37.5 (146) & & $36.2(83)$ & $63.8(146)$ & \\
\hline \multicolumn{8}{|c|}{ AVERAGE ANUAL İNCOMEA } \\
\hline$<1000 \mathrm{TL}$ & $9.0(97)$ & $63.9(62)$ & $36.1(35)$ & 0.837 & $39.7(23)$ & $60.3(35)$ & 0.669 \\
\hline $1000-2000 \mathrm{TL}$ & $23.9(257)$ & $61.5(158)$ & $38.5(99)$ & & $32.2(47)$ & $67.8(99)$ & \\
\hline $2000-3000 \mathrm{TL}$ & $17.7(190)$ & $64.2(122)$ & $35.8(68)$ & & $34.0(35)$ & $66.0(68)$ & \\
\hline$>3000 \mathrm{TL}$ & $23.8(255)$ & $60.4(154)$ & $39.6(101)$ & & $30.8(45)$ & $69.2(101)$ & \\
\hline
\end{tabular}

\section{$P<.05$ in bold.}

${ }^{A}$ Reduced because internal dropout.

It was found that when the education level of the parents increased, the caries prevalence of the children decreased. While not statistically significant ( $P$ $>.05)$, children whose mothers (63.4\%) and fathers $(64.2 \%)$ had graduated from primary schools were more likely to have ECC. Additionally, this study reported that ECC was more commonly found in children in low socioeconomic groups, whereas children with no carious lesions lived in high socioeconomic conditions. However, socioeconomic status was not associated with ECC $(P>.05)$.

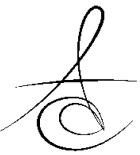


Table 2. Mean value and standard deviations of decayed, missing and filling teeth. Children monitored from 3 to 6 years of age $(n=1014)$.

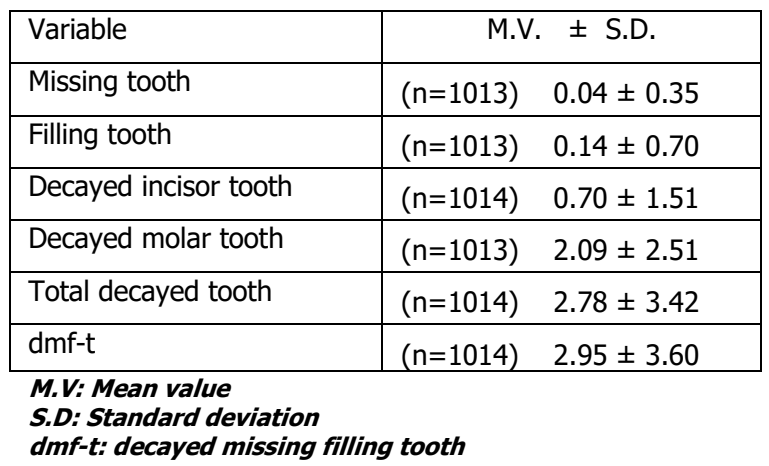

\section{Breastfeeding and consumption of dairy products}

The length of breastfeeding, the consumption of dairy products, tooth brushing habits and the history of dental visits of children with ECC and S-ECC are presented in Table 3. It was reported that $60.9 \%$ of children were breastfed longer than six months. Children who were breastfed more than six months had a higher prevalence of ECC than children who were breastfed less than six months, and the difference was statistically significant $(P<.05)$. However, the relationship between the consumption of bovine milk and an increase in early childhood caries was not statistically significant $(P>.05)$.

According to the answers to a related question, it was determined that $95(20 \%)$ of children did not eat any cheese, but $387(80 \%)$ of children ate cheese. Thus, children who did not consume any cheese were more likely to get ECC. A similar situation goes for yogurt consumption. In accordance with parents' answers, it was detected that $32(7 \%)$ of children did not eat yogurt, but 446 (93\%) of children ate yogurt. The study showed that children who consumed yogurt had less dental caries in their primary teeth. Children who ate calcium-containing foods, such as yogurt and cheese, had a significantly lower prevalence of ECC than those who did not $(P<.05)$. Frequency of cheese consumption was classified as $\leq 1$ time, 1-3 times or $\geq 4$ times per week. Similarly, children were classified into three groups: those with yogurt consumption $\leq$ once, those with yogurt consumption 1-3 times and those with yogurt consumption $\geq 4$ times per week. However, in the statistical analyses, frequencies of cheese and yogurt intake were not associated with early childhood caries $(P>.05)$.

Table 3. Univariate variable analysis of the duration of breastfeeding, consumption of dairy products, oral health habits and dental visits of children with ECC and S-ECC ( $n=$ 1077).

\begin{tabular}{|c|c|c|c|c|c|c|c|}
\hline Variable & $\begin{array}{c}\text { All children } \\
(n=1071) \\
\%(n)\end{array}$ & $\begin{array}{c}\text { ECC } \\
(n=610) \\
\%(n)\end{array}$ & $\begin{array}{c}\text { Non-ECC } \\
(n=361) \\
\%(n)\end{array}$ & P-value & $\begin{array}{c}\text { S-ECC } \\
(n=220) \\
\%(n)\end{array}$ & $\begin{array}{c}\text { Non-ECC } \\
(n=361) \\
\%(n)\end{array}$ & P-value \\
\hline \multicolumn{8}{|c|}{ Duration of breastfeeding ${ }^{a}$} \\
\hline$\leq 6$ months & $47.4(508)$ & $59.6(303)$ & $40.4(205)$ & $<0.05$ & $29.8(87)$ & $70.2(205)$ & $<0.05$ \\
\hline$>6$ months & $30.3(325)$ & $66.5(216)$ & 33.5 (109) & & $40.1(73)$ & 59.9 (109) & \\
\hline \multicolumn{8}{|c|}{ Milk consumption ${ }^{\mathrm{a}}$} \\
\hline Yes & $71.5(766)$ & $62.0(475)$ & $38.0(291)$ & 0.505 & $33.4(146)$ & $66.6(291)$ & 0.470 \\
\hline No & $7.3(79)$ & $65.8(52)$ & $34.2(27)$ & & $40.0(18)$ & $60.0(27)$ & \\
\hline \multicolumn{8}{|c|}{ Cheese consumption $^{\mathrm{a}}$} \\
\hline Yes & $64.0(686)$ & $61.1(419)$ & $38.9(267)$ & 0.147 & $31.0(120)$ & $69.0(267)$ & $<0.05$ \\
\hline No & $14.5(156)$ & $67.3(105)$ & $32.7(51)$ & & $46.3(44)$ & $53.7(51)$ & \\
\hline \multicolumn{8}{|c|}{ Yogurt consumption $^{\text {a }}$} \\
\hline Yes & $72.8(780)$ & $61.8(482)$ & $38.2(298)$ & $<0.05$ & $33.2(148)$ & $66.8(298)$ & $<0.05$ \\
\hline No & $5.5(59)$ & $74.6(44)$ & $25.4(15)$ & & $53.1(17)$ & $46.9(15)$ & \\
\hline \multicolumn{8}{|c|}{ Tooth brushing habit $^{\mathrm{a}}$} \\
\hline Yes & $40.7(436)$ & $58.3(254)$ & 41.7 (182) & $<0.05$ & $29.5(76)$ & 70.5 (182) & $<0.05$ \\
\hline No & $38.7(415)$ & $66.7(277)$ & $33.3(138)$ & & $39.2(89)$ & $60.8(138)$ & \\
\hline \multicolumn{8}{|c|}{ Daily brushing frequency ${ }^{a}$} \\
\hline Once a day & $48.8(523)$ & $64.8(339)$ & $35.2(184)$ & 0.122 & $37.6(111)$ & $62.4(184)$ & $<0.05$ \\
\hline Twice a day & $24.4(262)$ & $59.2(155)$ & $40.8(107)$ & & $28.2(42)$ & 71.8 (107) & \\
\hline \multicolumn{8}{|c|}{ Dental problem ${ }^{a}$} \\
\hline Yes & $19.0(204)$ & $87.3(178)$ & $12.7(26)$ & $<0.001$ & $79.4(100)$ & $20.6(26)$ & < 0.001 \\
\hline No & $59.9(642)$ & $54.5(350)$ & $45.5(292)$ & & $18.2(65)$ & $81.8(292)$ & \\
\hline \multicolumn{8}{|c|}{ Dental visit in the past ${ }^{\mathrm{a}}$} \\
\hline Yes & $22.0(236)$ & $72.0(170)$ & $28.0(66)$ & $<0.001$ & $23.9(79)$ & $76.1(251)$ & $<0.001$ \\
\hline No & $55.6(596)$ & $57.9(345)$ & $42.1(251)$ & & $54.2(78)$ & $45.8(66)$ & \\
\hline
\end{tabular}

\section{$P<.05$ in bold.}

${ }^{a}$ Reduced because internal dropout.

\section{Oral health practices}

While $415(48.8 \%)$ of children did not clean their teeth, $436(51.2 \%)$ of children brushed their teeth. ECC was identified in 277 (66.7\%) of the children who had never brushed their teeth. The relationship between tooth brushing and the prevalence of ECC was statistically significant $(P<.05)$.

In the present study, $523(66.6 \%)$ of the children brushed their teeth once a day, whereas 262 (33.4\%) of them brushed their teeth twice a day. The association between the frequency of toothbrushing and ECC prevalence was not found to be statistically 
significant $(P>.05)$. However, there was a higher prevalence of S-ECC among children that brushed their teeth once a day than those brushed their teeth twice a day $(P<.05)$.

\section{Dental visits}

According to the results of the study, 236 (28.4) of children had been to the dentist before. Of those children who had visited the dentist, 170 (72\%) were reported to have dental caries. However, 596 (71.6\%) of children had never been to a dentist, and $251(42.1 \%)$ of these children who had not visited a dentist before did not have any carious lesions. Dental visits were significantly associated with having ECC ( $P$ $<.001)$.

Eight variables identified as being statistically significant in univariate analysis were entered into the multivariable logistic regression models (Table 4). The results showed that yogurt consumption prevents the formation of dental caries (OR 0.4; 95\% CI 0.1 - 1.0). Additionally, this analysis confirmed that unless a child had a dental problem, his/her parent did not go to a dentist (OR 6.2; 95\% CI 3.1 - 12.3).

Table 4. Results from multivariable logistic regression analysis exploring the association between statistically significant risk factors and ECC.

\begin{tabular}{|c|c|c|}
\hline Variable & OR & $95 \%$ CI \\
\hline Age & 2.2 & $1.1-4.8$ \\
\hline Duration of breastfeeding & 1 & $0.5-1.4$ \\
\hline Cheese consumption & 1 & $0.5-1.7$ \\
\hline Yogurt consumption & 0.4 & $0.1-1.0$ \\
\hline Tooth brushing habit & 0.7 & $0.4-2.0$ \\
\hline Daily toothbrushing frequency & 0.9 & $0.5-1.5$ \\
\hline Dental problem & 6.2 & $3.1-12.3$ \\
\hline Dental visit in the past & 0.8 & $0.4-1.5$ \\
\hline
\end{tabular}

\section{DISCUSSION}

ECC is still a serious health problem in developed and developing countries, even though scientific studies have indicated that there has been a decrease in dental caries in the last decade. ECC has destructive effects on both children and their families. Furthermore, restorative and surgical treatments are not permanent solutions, and there has not been enough studies related to ECC. Therefore, this study supplies necessary information on the dental conditions among children going to preschools in Trabzon and the risk factors associated with ECC.

This study found a high prevalence of ECC and S-ECC (63.1\% and 20.4\%, respectively) among preschool children aged $3-6$ years who were living in Trabzon. The prevalence of ECC and S-ECC in this research is not only significantly higher than that in children living in Nigeria $(23.5 \%$ and $2.2 \%$, respectively) in $2014,{ }^{15}$ but it is also higher than that in children from neighbouring developing countries, including Iran (33\%). ${ }^{16}$ While the proportion of 6 year-old German children with a healthy dentition in 2000 was $33.3 \%-60.2 \%$, an increase in the proportion of 6-year-olds with caries-free primary dentition to no less than $80 \%$ by 2020 is one of Germany's oral health goals. ${ }^{17}$ The prevalence of ECC in 5 -year-old children (71.7\%) is three-fold higher than that in India (24.83\%). This study is consistent with others that showed that the prevalence of caries increases with age. ${ }^{18,19}$ The mean dmf-t score of children in Trabzon was calculated as $2.95 \pm 3.60$, and the distribution by ages is $2.01 \pm 3.43$ in 3-yearolds, $2.40 \pm 3.41$ in 4-year-olds and $3.51 \pm 3.69$ in 5year-olds. While the child is growing, dietary habits, oral microbiota and oral hygiene practices change. This is because the cariogenic environment and dental caries would increase.

A study showed that dental caries affects boys much more than girls in India. ${ }^{20}$ On the other hand, another survey in Nigeria reported that the prevalence of ECC is higher in females $(66.7 \%)$ compared to males $(33.3 \%)$, and the difference was statistically significant. ${ }^{21}$ Similar to the survey described by Folayan et al., it was observed that girls had a higher prevalence of ECC than boys in this study. However, there was no significant difference in ECC prevalence between boys and girls.

ECC is a social, political, behavioural and medical problem. Additionally, it shifts social and economic responsibility to both the family and society. Financial, social and material disadvantages are most commonly seen in children from lower socioeconomic groups because they are not able to obtain professional oral healthcare services. The present study showed caries prevalence to be highest in the low socioeconomic group, but the difference was not statistically significant. This finding is similar to that reported by Stephan et al. $^{18}$, but it opposed the

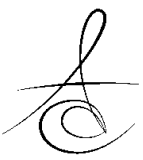


findings of another survey, which showed a higher prevalence of ECC among children in high socioeconomic groups. ${ }^{22}$ Although Ozen et al. ${ }^{23}$ showed that higher caries experience was seen in children whose parents' education level was lower, there was no statistically significant relationship between parental education level and dental caries formation in this study. This is because highly educated parents can control the diet and oral hygiene practices of their children.

Although breastfeeding offers physical, emotional and economic benefits ${ }^{24}$, the role of human milk in the aetiology of early childhood caries is still a debatable issue. This study showed that breastfeeding longer than six months increases the occurrence of ECC, similar to the results of Prakash et al. and Kakanur et al. ${ }^{25,26}$ This is in contrast with a study by Jain et al., who found that there is an elevated risk of dental caries with no breastfeeding compared to breastfeeding up to 12 months of age. ${ }^{27}$

Experimental studies have demonstrated that bovine milk is non-cariogenic because of its low concentration of lactose and high mineral content. ${ }^{28,29}$ Therefore, it is not a primary causative agent in the induction of ECC. Additionally, there was no significant relationship between the consumption of bovine milk and the increase of early childhood caries in the present study. Dairy products such as cheese and yogurt are advantageous in promoting the oral health of children. These products, which include calcium, phosphorus and casein, encourage tooth remineralization and decrease the demineralization of enamel and bacterial adhesion. ${ }^{30}$ Previous studies have shown that cheese has a cariostatic effect because it increases the calcium content in saliva and dental plaque. ${ }^{31}$ Similarly, the results from this study indicate that cheese consumption in children decreases the severity of caries and the progression of caries lesions. Additionally, while milk and yogurt have similar compositions, yogurt has a greater protective effect than milk against dental caries. This may be because the ultimate components of yogurt after fermentation are different from those of milk, and the concentration of casein phosphopeptide in yogurt is higher than in milk. ${ }^{30}$ The present study, which found that yogurt consumption prevents the formation of dental caries in children, is consistent with research by Tanaka et al. ${ }^{32}$ In this regard, it has been demonstrated that children who eat dairy products, such as cheese and yogurt, have significantly lower rates of dental caries.

Tooth brushing is regarded as an important tool in the prevention of dental caries in children. In this study, population, children who did not have a regular tooth brushing habit had significantly more dental caries than the others. Moreover, children who brushed their teeth once a day had a higher incidence of S-ECC than those who brushed their teeth twice a day. However, there was not a significant relationship between tooth brushing frequency and ECC in this survey. Similarly, it was shown that tooth brushing frequency was associated with the occurrence of ECC in previous studies. ${ }^{25,} 27$

The American Academy of Paediatrics (AAP) recommends that parents should visit the dental office with a six-month-old baby after the eruption of the first tooth or no later than the child's first birthday. ${ }^{33}$ Early dental visits have been related to lower ECC experience in the US. ${ }^{34}$ However, only $28.4 \%$ of children had been to a dentist prior to this study, and $72 \%$ of children who had visited the dentist before were reported to have dental caries. Almost half $(42.1 \%)$ of children who had not visited a dentist before did not have any carious lesions. This situation is probably associated with parents who believe that it is not worthwhile to spend time and money on baby teeth because they will ultimately be lost. They only visit the dental office with their children when they have pain, fever and/or swelling. The present study confirms that dental visits are significantly related to preschool children having dental caries. Moreover, previous studies found a higher caries incidence in children who had visited a dentist. ${ }^{35,36}$

\section{CONCLUSION}

In conclusion, ECC and S-ECC remain serious public health problems among preschool children in Trabzon. This study seeks to increase the awareness of dentists, paediatricians, physicians, and nurses of the prevention, diagnosis and treatment of ECC and SECC. Furthermore, parents' awareness of the prevalence, severity and effects of ECC on general and oral health, growth and development of children should be increased. In addition, preschool children should be encouraged to consume more dairy 
products, such as cheese and yogurt, to prevent dental caries. The present survey showed that preschool children's oral health and parental education for the prevention of ECC should be emphasized.

Sema Aydınoğlu: ORCID ID: 0000-0003-1490-8645 Adem Kuşgöz: ORCID ID: 0000-0002-8420-3491

\section{REFERENCES}

1. Qin M, Li J, Zhang S, Ma W. Risk factors for severe early childhood caries in children younger than 4 years old in Beijing, China. Pediatr Dent 2008;30:122-8.

2. American Academy of Pediatric Dentistry. Policy on early childhood caries (ECC): Classifications, consequences, and preventive strategies. Pediatr Dent 2016;40:60-2.

3. American Academy on Pediatric Dentistry. Definition of Early Childhood Caries (ECC). Pediatr Dent 2008;15.

4. Seow WK, Clifford $H$, Battistutta D, Morawska A, Holcombe T. Case-control study of early childhood caries in Australia. Caries Res 2009;43:25-35.

5. Poureslami HR, Van Amerongen WE. Early childhood caries (ecc): An infectious transmissible oral disease. Indian $\mathrm{J}$ Pediatr 2009;76:191-4.

6. Survey NHANES. Reduce the proportion of children aged 3 to 5 years with dental caries experience in their primary teeth. From https://www.healthypeople.gov/2020/datasearch/ 2016.

7. Araz $M$, Güven $Y$, Aktören $O$. Bebeklerde beslenme modelleri ve erken çocukluk çağı çürükleri. Journal of Ataturk Uni Dent 2015; 11 : 64-70.

8. Congiu G, Campus G, Luglie PF. Early childhood caries (ECC) prevalence and background factors: a review. Oral Health Prev Dent 2014;12:71-6.

9. Dallı $M$, Dulgergil ÇT, Hamidi MM, Mutluay AT, Doğan D, Akkuş Z. Different ECC patterns from Turkey: 4-centered epidemiologic study for 1 to 3 years old children. $5^{\text {th }}$ Conseuro İstanbul. 2011:13-5.
10. Kızılcı E, Ozalp N. Çocuklara streptokokkus mutans geçişinin değerlendirilmesi: etkili faktörler ve enfektivite penceresi. Atatürk Univ Diş Hek Fak Derg 2015;11:71-6.

11. Tinanoff N, Reisine S. Update on early childhood caries since the surgeon general's report. Acad Pediatr 2009;9:396-403.

12. Kagihara LE, Niederhauser VP, Stark $M$. Assessment, management, and prevention of early childhood caries. J Am Acad Nurse Pract 2009;21:1-10.

13. Lemeshow S, Hosmer DW, Klar J, Lwanga SK. Adequency of sample size in health studies; 2000:142-3.

14. World Health Organization. Oral health surveys: basic methods, Fifth edition. 2013.

15. Iyun OI, Denloye OO, Bankole OO, Popoola BO. Prevalence and pattern of early childhood caries in Ibadan, Nigeria. Afr J Med Med Sci 2014;43:239-44.

16. Mohebbi Simin Z, Virtanen Jorma I, VahidGolpayegani M, Vehkalahti Miira M. Early childhood caries and dental plaque among 1-3-year-olds in Tehran, Iran. J Indian Soc Pedod Prev Dent 2006;24:177-81.

17. Ziller S, Micheelis W, Oesterreich D, Reich E. Goals for oral health in Germany 2020. Int Dent J 2006;56:29-32.

18. Stephen A, Krishnan R, Ramesh M, Kumar VS. Prevalence of early childhood caries and its risk factors in 18-72 month old children in Salem, Tamil nadu. J Int Soc Prev Community Dent 2015;5:95-102.

19. Li Y, Wulaerhan J, Liu Y, Abudureyimu A, Zhao J. Prevalence of severe early childhood caries and associated socioeconomic and behavioral factors in Xinjiang, China: a cross-sectional study. 2017;17:144.

20. Kuriakose S, Prasannan M, Remya KC, Kurian J, Sreejith KR. Prevalence of early childhood caries among preschool children in Trivandrum and its association with various risk factors. Contemp Clin Dent 2015;6:69-73.

21. Folayan MO, Kolawole KA, Oziegbe EO, Oyedele $\mathrm{T}$, Oshomoji OV, Chukwumah NM, et al. Prevalence, and early childhood caries risk indicators in preschool children in suburban Nigeria. BMC Oral Health 2015;15:72. 
22. Olatosi $\mathrm{OO}$, Inem $\mathrm{V}$, Sofola $\mathrm{OO}$, Prakash $\mathrm{P}$, Sote EO. The prevalence of early childhood caries and its associated risk factors among preschool children referred to a tertiary care institution. Niger J Clin Pract 2015;18:493-501.

23. Ozen B, Van Strijp AJ, Ozer L, Olmus $H$, Genc A, Cehreli SB. Evaluation of possible associated factors for early childhood caries and severe early childhood caries: A multicenter crosssectional survey. J Clin Pediatr Dent 2016; 40: 118-23.

24. Feldman-Winter L, Goldsmith JP, Committee On F, Newborn, Task Force On Sudden Infant Death S. Safe sleep and skin-to-skin care in the neonatal period for healthy term newborns. Pediatrics 2016;138.

25. Prakash $P$, Subramaniam $P$, Durgesh $B H$, Konde S. Prevalence of early childhood caries and associated risk factors in preschool children of urban Bangalore, India: A cross-sectional study. Eur J Dent 2012;6:141-52.

26. Kakanur M, Nayak M, Patil SS, Thakur R, Paul ST, Tewathia N. Exploring the multitude of risk factors associated with early childhood caries. Indian J Dent Res 2017;28:27-32.

27. Jain M, Namdev R, Bodh M, Dutta $S$, Singhal $P$, Kumar A. Social and behavioral determinants for early childhood caries among preschool children in India. J Dent Res Dent Clin Dent Prospects 2015;9:115-20.

28. Bowen $W H$, Lawrence RA. Comparison of the cariogenicity of cola, honey, cow milk, human milk, and sucrose. Pediatrics 2005;116:921-6.

29. Kawashita Y, Kitamura M, Saito T. Early childhood caries. Int J Dent 2011;2011:725320.

30. Ferrazzano GF, Cantile $T$, Quarto M, Ingenito $A$, Chianese L, Addeo F. Protective effect of yogurt extract on dental enamel demineralization in vitro. Aust Dent J 2008;53:314-9.

31. Merritt J, Qi F, Shi W. Milk helps build strong teeth and promotes oral health. J Calif Dent Assoc 2006; 34: 361-6.

32. Tanaka K, Miyake $Y$, Sasaki S. Intake of dairy products and the prevalence of dental caries in young children. J Dent 2010;38:579-83.

33. American Academy on Pediatric Dentistry. Policy on the dental home. Pediatr Dent 2018;29-30.
34. Beil $H$, Rozier RG, Preisser JS, Stearns SC, Lee JY. Effects of early dental office visits on dental caries experience. Am J Public Health 2014;104:1979-85.

35. Nobile CG, Fortunato L, Bianco A, Pileggi C, Pavia $M$. Pattern and severity of early childhood caries in Southern Italy: A preschool-based crosssectional study. BMC Public Health 2014;14:206.

36. Fan $C$, Wang $W, X u T$, Zheng S. Risk factors of early childhood caries among children in Beijing: A case-control study. BMC Oral Health 2016;16:98.

\section{Yazışma Adresi}

Dr. Öğr. Üyesi Sema AYDINOĞLU

Recep Tayyip Erdoğan Üniversitesi

Diş Hekimliği Fakültesi

Fener - Menderes Bulvarı -

No:64 Merkez- Rize

e-mail: semapilak@hotmail.com 